\title{
In situ sulfur and lead isotope analyses of the Jinlongshan gold deposit in Southern Qinling Orogen, China: Implications for ore-forming source
}

Yuanbo Ma1, Laimin Zhu1*, Lele Ding1, Xiao Xiong1, Bei Lil

1State Key Laboratory of Continental Dynamics, Department of Geology, Northwest University, No.229 Taibai Road, Xi'an 710069, China

(*Correspondence: zhulaimin@nwu.edu.cn)

The Jinlongshan gold deposit, Shaanxi province, central China, is a large gold deposit $(>150 \mathrm{t} \mathrm{Au})$ in the Southern Qinling Orogen. Structurally controlled gold mineralization is hosted in Upper Devonian to Lower Carboniferous carbonaceous clastic-carbonate sequences. Although it had been widely studied by geologists, oreforming sources of deposit remains debatable, while both intrusion-linked and non-intrusion linked models have been proposed [1,2].

In this paper, in situ sulfur and lead isotope analysis were performed on a diverse set of sulfides of different generations to trace the ore-forming sources as well as the genetic mechanism of $\mathrm{Au}$ mineralization. Three stage sulfides were identified from Jinlongshan gold deposit. Sulfur isotope analyses of sulfides by LA-MC-ICPMS show a wide range of $\delta^{34} \mathrm{~S}$ values from $-29.9 \%$ to $+48.4 \%$. Pre-ore stage pyrite $\left(\delta^{34} \mathrm{~S}\right.$ Py $1=-29.9 \%$ to $+42 \%$ ) formed by bacterial sulfate reduction of Upper Devonian marine sulfate. Ore stage sulfides $\left(\delta^{34} \mathrm{~S}_{\mathrm{Py} 2}=10.1 \%\right.$ to $15.3 \%, \delta^{34} \mathrm{~S}_{\mathrm{Apy}}=$ $9.6 \%$ to $13.8 \%$ o, $\delta^{34} \mathrm{~S}_{\mathrm{Snt}}=13.9 \%$ o to $14.3 \%$ ) have restricted range of $\delta^{34} \mathrm{~S}$ values that are interpreted to result from the underlying Paleozoic sedimentary rocks by decomposition of pyrite and/or inorganic reduction of sulfate. Post-ore stage pyrite $\left(\delta^{34} \mathrm{SPy}_{3}=-4.4 \%\right.$ o to $+48.4 \%$ ) formed by mixing of shallow meteoric water with sedimentary components (negative $\delta^{34} \mathrm{~S}$ values) and deep fluids (extremely high $\delta^{34} \mathrm{~S}$ values). Likewise, the $\mathrm{Pb}$ isotope compositions of ore stage sulfides resemble those of underlying Paleozoic sedimentary rocks, but are different from Precambrian metamorphic basement rocks and granitoids in the basin. From these observations, we proposed the sulfur and ore metals of the Jinlongshan gold deposit were sourced from the underlying Paleozoic sedimentary rocks.

[1] Chen (2015) MD 50, 643-656. [2] Liu (2015) J Asian Earth Sci $103,40-69$. 